\title{
Polymorphisms in the ovine myostatin gene are associated with birth weight but not with weight gain in Iranian Makoei sheep
}

\author{
M. Farhadian ${ }^{1}$, A. Hashemi ${ }^{2}$, K. Mardani $^{3}$, R. Darvishzadeh ${ }^{4,5}$ \\ and S. Jafari ${ }^{2}$ \\ ${ }^{1}$ Young Researchers Club, Islamic Azad University, Khoy Branch, Khoy, Iran \\ ${ }^{2}$ Department of Animal Science, Faculty of Agriculture, \\ Urmia University, Urmia, Iran \\ ${ }^{3}$ Department of Food Hygiene and Quality Control, \\ Faculty of Veterinary Medicine, Urmia University, Urmia, Iran \\ ${ }^{4}$ Institute of Biotechnology, Urmia University, Urmia, Iran \\ ${ }^{5}$ Department of Agronomy and Plant Breeding, Urmia University, Urmia, Iran \\ Corresponding author: M. Farhadian \\ E-mail: mohammad.farhadian@yahoo.com
}

Genet. Mol. Res. 11 (4): 3568-3575 (2012)

Received October 13, 2011

Accepted September 16, 2012

Published October 4, 2012

DOI http://dx.doi.org/10.4238/2012.October.4.4

\begin{abstract}
Myostatin, a transforming growth factor-beta superfamily member, has been well documented as a negative regulator of muscle growth and development. Myostatin, which has 376 amino acids, is synthesized as a precursor protein. Polymorphism of the myostatin gene in Makoei sheep was investigated by PCR and single-strand conformation polymorphism technique (SSCP). Genomic DNA of 92 sheep was isolated from whole blood. A 417-bp myostatin intron I segment was amplified by standard PCR, using locus-specific primers. Four SSCP patterns, representing four different genotypes, were identified. The frequencies of the genotypes were $0.413,0.293,0.130$, and 0.163 for $\mathrm{AD}, \mathrm{AC}, \mathrm{AE}$, and $\mathrm{BC}$, respectively. Allele frequencies were 0.4185, $0.0815,0.2283,0.2065$, and 0.0652 for $\mathrm{A}, \mathrm{B}, \mathrm{C}, \mathrm{D}$, and $\mathrm{E}$, respectively.
\end{abstract}


Observed heterozygosity was 0.7192 . There was significant deviation from Hardy-Weinberg equilibrium for this locus. Analysis of myostatin gene sequences revealed heterozygous SNPs, which were in agreement with results obtained in the SSCP analysis. We concluded that SSCP analysis is a quick, sensitive and reliable technique for determination of DNA polymorphisms. The effect of these genotypes on some traits was investigated, and the AD genotype was found to be associated with birth weight. No phenotypic associations were detected with the other genotypes. No associations of myostatin variants with weight gain were detected. We conclude that polymorphism in the ovine myostatin gene is associated with birth weight, but not with weight gain in Iranian Makoei sheep.

Key words: Myostatin gene; PCR; SSCP; SNP; Makoei sheep

\section{INTRODUCTION}

Myostatin, a transforming growth factor-beta superfamily member, negatively regulates skeletal muscle mass development by inhibiting the Myo5 and MyoD factors, which are involved in the differentiation of precursor cells into myoblasts (McPherron and Lee, 1997). Myostatin protein is first synthesized in the skeletal muscle as a $52-\mathrm{kDa}$ propeptide and then prototypically processed at the conserved RSRR (arginine-serine-arginine-arginine) site to produce a $40-\mathrm{kDa}$ latency-associated peptide and a $13-\mathrm{kDa}$ mature peptide that form a homodimer $(26 \mathrm{kDa})$ that binds to its receptor(s) to perform its biological functions (Herpin et al., 2004).

The myostatin gene consists of 3 exons and 2 introns (Bellinge et al., 2005). The effects of the myostatin gene were first described in mice, in which loss of myostatin expression in knockout mice is associated with an increase in both the number (hyperplasia) and size (hypertrophy) of muscle fibers. The muscles of myostatin knockout mice weighed about twice as much as those of wild-type mice. In the Belgian Blue and Piedmontese cattle, an extreme form of muscularity (double muscling) results from mutations in the coding region of the myostatin gene (Kambadur et al., 1997; McPherron and Lee, 1997; Wiener et al., 2009).

The ovine myostatin gene is located on chromosome 2. Single-strand conformational polymorphism (SSCP) analysis of the intron I region of this gene revealed 5 allelic variants in the New Zealand Romney sheep breed (Hickford et al., 2009). Single-nucleotide polymorphism (SNP) in the 3'-untranslated region of the myostatin gene has been shown to affect muscularity in sheep (Clop et al., 2006; Kijas et al., 2007). Additional SNPs associated with muscling have also been identified in the promoter and intron II regions (Kijas et al., 2007). In total, 23 ovine myostatin gene SNPs have been reported (Clop et al., 2006; Kijas et al., 2007; Zhou et al., 2008), and whereas SNPs provide some indication of the structural diversity of a gene, extended haplotypes are typically more informative, especially if they encompass all or most of the coding region. To date, 4 haplotypic variants positioned at $41,+4036$, and +6223 have been constructed from the coding sequence using SNPs in the myostatin gene (Kijas et al., 2007).

Quantitative trait locus studies in sheep have shown that the myostatin gene has a major effect on muscular development in Belgian Texel (Marcq et al., 2002) and muscling depth in New Zealand Romney (Hickford et al., 2009), Norwegian White (Boman et al., 2009), Cha- 
rollais (Hadjipavlou et al., 2009), and New Zealand Texel sheep (Johnson et al., 2009). The objective of present study was to characterize potential variations in the ovine myostatin gene and their association with birth weight and weight gain in Iranian Makoei sheep.

\section{MATERIAL AND METHODS}

\section{Blood sample collection and genomic DNA extraction}

Makoei sheep are fat-tailed sheep with medium bodies. They are white with black spots on the face and feet and are raised in the eastern and western Azerbaijan Provinces (Iran) mainly for meat and wool (Saadat-Noori and Siah-Mansoor, 1992). Blood samples (approximately 2-3 mL) were obtained from 92 unrelated Makoei rams coming from various parts of western Azerbaijan and stored in ethylenediaminetetraacetic acid (EDTA)-coated tubes. Genomic DNA was extracted from $0.2 \mathrm{~mL}$ blood using a genomic DNA purification kit (Fermentas, USA) according to manufacturer instructions. The quality and quantity of extracted DNA was measured on $0.8 \%$ agarose gel prepared in $0.5 \mathrm{X}$ TBE buffer ( $45 \mathrm{mM}$ Tris-base, $45 \mathrm{mM}$ boric acid, $1 \mathrm{mM}$ EDTA, $\mathrm{pH}$ 8.0), visualized with ethidium bromide $(1.0 \mu \mathrm{g} / \mathrm{mL})$ under ultraviolet light, and photographed.

\section{Amplification of intron I of the myostatin gene}

Two polymerase chain reaction (PCR) primers - myostatin-up (5'-GAAACGGGTCAT TACCATGC-3') and myostatin-down (5'-CATATTTCAGGCAACCAAATG-3') - targeting a fragment of 417 bp were used for DNA amplification as described by Zhou et al. (2008). The PCR was carried out in a $50-\mu \mathrm{L}$ volume using a PCR Master Mix kit (CinnaGen Inc., Tehran, Iran) containing 2.5 U Taq DNA polymerase in reaction buffer, $4 \mathrm{mM} \mathrm{MgCl}, 50$ $\mu \mathrm{M}$ of each dNTP (dATP: deoxyadenosine triphosphate, dCTP: deoxycytidine triphosphate, dGTP: deoxyguanosine triphosphate, and dTTP: deoxythymidine triphosphate), $0.5 \mu \mathrm{M}$ of each primer, and $100 \mathrm{ng}$ extracted DNA as a template. DNA amplifications were performed using a Mastercycler (Eppendorf, Germany) programmed for a preliminary step of 2 min at $94^{\circ} \mathrm{C}$, followed by 35 cycles of $45 \mathrm{~s}$ at $94^{\circ} \mathrm{C}, 45 \mathrm{~s}$ at $52^{\circ} \mathrm{C}$, and $45 \mathrm{~s}$ at $72^{\circ} \mathrm{C}$, with a final extension of $2 \mathrm{~min}$ at $72^{\circ} \mathrm{C}$.

\section{SSCP}

PCR products were mixed with $8 \mu \mathrm{L}$ denaturing loading dye [95\% (w/v) deionized formamide, $0.05 \%(\mathrm{w} / \mathrm{v})$ xylene cyanol, $0.05 \%(\mathrm{w} / \mathrm{v})$ bromophenol blue, and $0.02 \mathrm{M}$ EDTA] in a total volume of $15 \mu \mathrm{L}$. The mixture was denatured at $95^{\circ} \mathrm{C}$ for $5 \mathrm{~min}$ and then snap-chilled on ice (Pipalia et al., 2004). The total volume was electrophoresed on $8 \%$ polyacrylamide gel, as described by Herring et al. (1982). The electrophoresis was performed in 0.5X TBE buffer at room temperature $\left(18^{\circ} \mathrm{C}\right)$ and a constant $200 \mathrm{~V}$ for $3 \mathrm{~h}$. Polyacrylamide gels were stained using silver nitrate according to the protocol described by Herring et al. (1982).

\section{Sequencing}

PCR products from various genotypes of the myostatin gene were subjected to DNA 
sequencing. Each PCR product $(10 \mu \mathrm{L})$ and $15 \mu \mathrm{L} 5 \mu \mathrm{M}$ myostatin-up primer were sent to CinnaGen for PCR cleanup and sequencing.

\section{Statistical analysis}

The allelic and genotypic frequencies and observed and expected Nei's heterozygosities $\left(H_{\mathrm{E}}=1-\Sigma P_{i}^{2}\right.$, where $P_{i}$ is the frequency of allele i) were estimated using PopGene32 version 1.31 (Yeh et al., 1997). PopGene32 was also used to perform the Hardy-Weinberg equilibrium test.

Data on growth traits were retrieved from the national sheep recording system. The following fixed-effects model was used to calculate breeding value by using DFRIMEL (derivative-free restricted maximum likelihood; Meyer, 2000):

$$
\mathrm{Y}_{\mathrm{ijklm}}=\mu+\mathrm{YR}_{\mathrm{i}}+\mathrm{SX}_{\mathrm{j}}+\mathrm{BT}_{\mathrm{k}}+\mathrm{AD}_{1}+\mathrm{AN}_{\mathrm{m}}+\mathrm{E}_{\mathrm{ijklm}}
$$

where $Y_{i j k l m}$ is the dependent variable (birth weight or weight gain) evaluated on the $\mathrm{i}^{\text {th }}$ level of year as a random factor $\left(Y R_{i}, \mathrm{I}=1,2,3, \ldots, 21\right)$, the $\mathrm{j}^{\text {th }}$ level of sex as a fixed factor $\left(S X_{j}, \mathrm{j}=1\right.$ and 2), the $\mathrm{k}^{\text {th }}$ level of offspring number in each birth as a fixed factor $\left(B T_{K}, \mathrm{~K}=1,2\right.$, and 3$)$, the $1^{\text {th }}$ level of mother age as a fixed factor $\left(A D_{l}, 1=1,2, \ldots, 7\right)$, and the $\mathrm{m}^{\text {th }}$ level of the random additive genetic effect $\left(A N_{m}, \mathrm{~m}=\right.$ number of animals for each trait). The variable $\mu$ is the overall mean for each trait, and $E_{i j k l m}{ }^{m}$ is the random error effect. SAS was used to calculate least squares means and to make multiple comparisons among the various genotypes in the Makoei breed.

\section{Sequence analysis}

All sequences were analyzed for SNPs and mutation through direct comparison of chromatograms using SeqDoC (Crowe, 2005).

\section{RESULTS}

We successfully amplified the intron I region of the myostatin gene (a fragment of $417 \mathrm{bp}$ in length) on our first attempt. All extracted DNAs from ram blood samples yielded a specific, single-band PCR product without nonspecific bands. Therefore, the PCR products were directly used for SSCP analysis.

The allelic variation in the myostatin gene was examined using a PCR-SSCP method. The non-denaturing gel electrophoresis allowed visualization of single-stranded DNA and SSCP band patterns. Four SSCP patterns were observed in the sheep (Figure 1). The frequencies of the observed genotypes were $0.413,0.293,0.130$, and 0.163 for $\mathrm{AD}, \mathrm{AC}, \mathrm{AE}$, and $\mathrm{BC}$, respectively. Allele frequencies were $0.4185,0.0815,0.2283,0.2065$, and 0.0652 for $\mathrm{A}, \mathrm{B}, \mathrm{C}$, $\mathrm{D}$, and $\mathrm{E}$, respectively (Table 1 ). The observed heterozygosity value was 1.0. The chi-square test showed significant $(\mathrm{P} \leq 0.05)$ deviation from Hardy-Weinberg equilibrium for the locus under study in the Makoei sheep population.

Sequence analysis using the SeqDoC software revealed heterozygous SNPs among all examined myostatin sequences (see Figure 1). All detected SNPs were located in the same region of the gene. The results of the sequence analysis confirmed the SSCP results.

General linear mixed models revealed that genotype AD was associated with birth 
weight in the Makoei sheep breed, but no association was found between the other genotypes ( $\mathrm{AC}, \mathrm{AE}, \mathrm{BC}$ ) and birth weight. The effect of the $\mathrm{AD}, \mathrm{AC}, \mathrm{AE}$, and $\mathrm{BC}$ genotypes on weight gain was non-significant (Table 2).
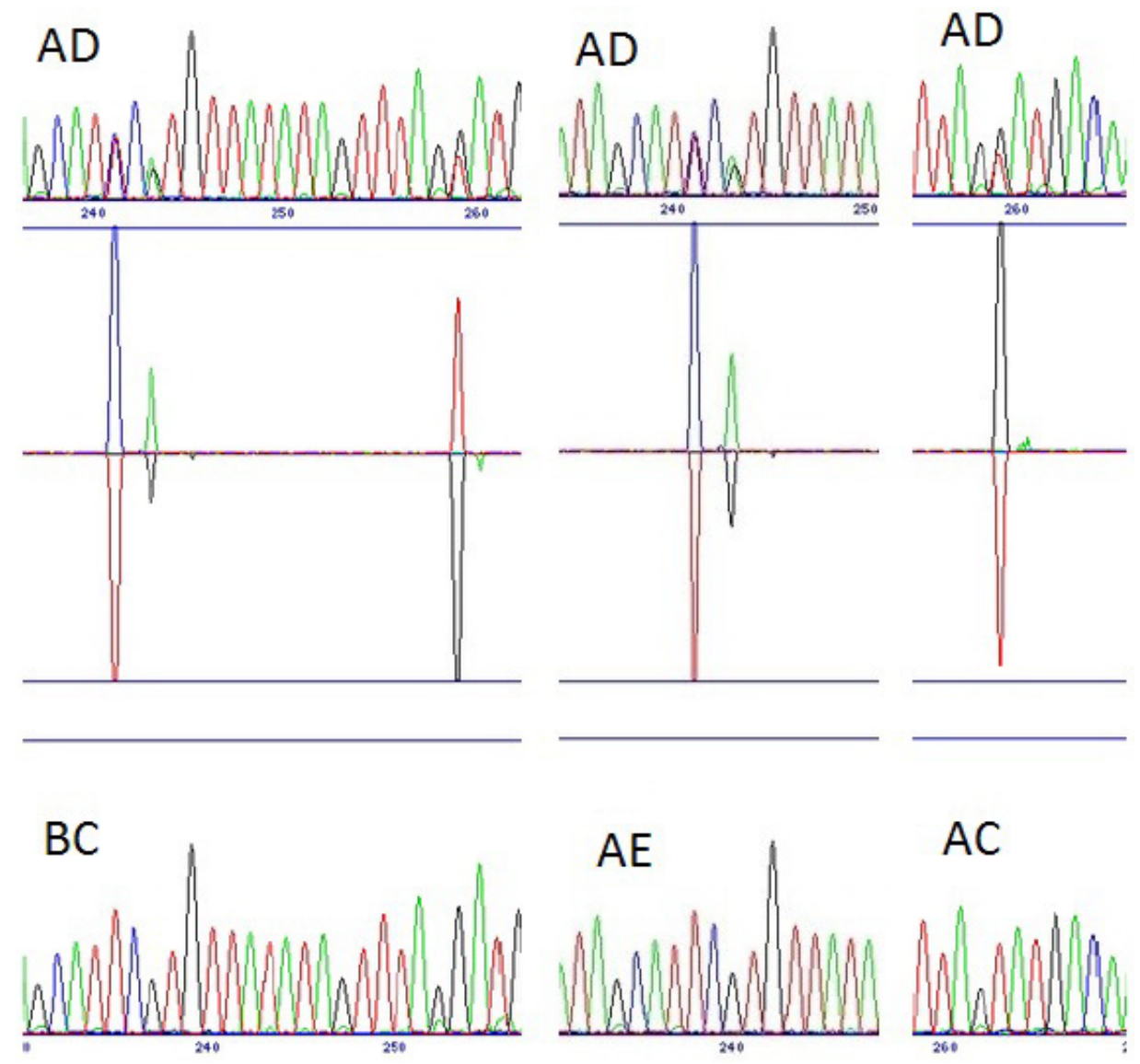

$\mathrm{AC}$

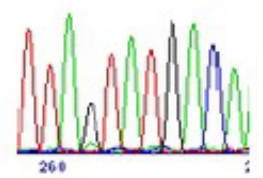

Figure1. SNPs profile of myostatin gene in Iranian "Makoei” sheep breed.

\begin{tabular}{|c|c|c|c|c|c|}
\hline Genetic diversity statistics & Value & Allele frequencies & Value & Genotypic frequencies & Value \\
\hline$N_{\mathrm{A}}$ & 5.00 & A & 0.42 & $\mathrm{AD}$ & 0.41 \\
\hline$N_{\mathrm{E}}^{\mathrm{A}}$ & 3.56 & B & 0.08 & $\mathrm{AC}$ & 0.29 \\
\hline$I^{\mathrm{E}}$ & 1.41 & $\mathrm{C}$ & 0.23 & $\mathrm{AE}$ & 0.13 \\
\hline Observed homozygosity & 0.00 & D & 0.21 & $\mathrm{BC}$ & 0.16 \\
\hline Observed heterozygosity & 1.00 & $\mathrm{E}$ & 0.07 & & \\
\hline Expected homozygosity & 0.28 & & & & \\
\hline Expected heterozygosity & 0.72 & & & & \\
\hline Average heterozygosity & 0.72 & & & & \\
\hline
\end{tabular}

$N_{\mathrm{A}}=$ observed number of alleles, $N_{\mathrm{E}}=$ effective number of alleles (Kimura and Crow, 1964); $I=$ Shannon's information index (Lewontin and Hubby, 1971). 
Table 2. Effect of the myostatin gene genotype on birth and gain weight in Iranian "Makoei" sheep breed.

\begin{tabular}{lccccc}
\hline $\mathrm{P}$ & \multicolumn{4}{c}{ Genotype } & \multirow{2}{*}{ Trait } \\
\cline { 2 - 4 } & $\mathrm{BC}$ & $\mathrm{AE}$ & $\mathrm{AC}$ & $\mathrm{AD}$ & \\
\hline $0 / 05$ & $0.046 \pm 0.015$ & $0.026 \pm 0.09$ & $0.011 \pm 0.0017$ & $0.068 \pm 0.020$ & Birth weight \\
NS & $0.068 \pm 0.178$ & $0.084 \pm 0.059$ & $0.059 \pm 0.092$ & $0.12 \pm 0.0570$ & Weight in 3 months \\
NS & $0.163 \pm 0.064$ & $0.089 \pm 0.051$ & $0.121 \pm 0.063$ & $0.13 \pm 0.037$ & Weight in 6 months \\
NS & $0.18 \pm 0.057$ & $0.145 \pm 0.109$ & $0.482 \pm 0.071$ & $0.172 \pm 0.063$ & Weight in 9 months \\
NS & $0.668 \pm 0.195$ & $0.380 \pm 0.301$ & $0.598 \pm 0.02$ & $0.88 \pm 0.169$ & Weight in 12 months \\
\hline \multicolumn{5}{l}{ NS $=$ not significant. }
\end{tabular}

\section{DISCUSSION}

In the present study, variation in the intron I region of the myostatin gene was analyzed in Makoei sheep using PCR-SSCP analysis. Five alleles (A, B, C, D, and E) and 4 genotypes (AD, $\mathrm{AC}, \mathrm{AE}$, and $\mathrm{BC})$ were observed in the intron I region of the myostatin gene. Allele $\mathrm{A}$ and genotype $\mathrm{AD}$ were the most frequent in the sheep, with frequencies of 0.42 and $0.41 \%$, respectively. The results of this study agree partly with those of Hickford et al. (2009), who observed 5 alleles in the myostatin gene in both New Zealand and Makoei sheep breeds.

In double-muscled cattle, 7 mutations occur in the myostatin gene - namely, nt821 (del 11), nt419 (del7-ins10), Q204X, E226X, C313Y, F94L, and nt414 (C-T) (Kambadur et al., 1997; Grobet et al., 1997; McPherron and Lee, 1997; Georges et al., 1998; Smith et al., 2000; Nishi et al., 2002). PCR products of the myostatin gene amplification in samples of 60 sheep from 9 Chinese indigenous sheep breeds and 1 imported sheep breed were sequenced to identify SNPs in a 378-bp fragment including intron II and exon III of the myostatin gene (Gong et al., 2009). Fifteen SNPs (A1937C, T1942G, C1956T, A1972C, A1990G, A2008C, A2011G, C2019T, A2025C, A2027C, T2085G, T2173C, C2198T, C2210T, and C2213T) were detected among these individuals, and they were all located in intron II.

We found that a higher number of studied animals carried alleles A and C. Only animals with genotype AD showed significantly different birth weight compared with those of the other groups (see Table 2). Among the 4 genotypes observed, 3 carried allele A (see Table 1). Significant difference in birth weight was found only in animals carrying genotype $A D$, so we concluded that allele $\mathrm{D}$ had a greater influence on the difference in birth weight. We do not believe that allele A had an influence, because we saw no significant differences between the $\mathrm{AD}$ and $\mathrm{AC}$ or the $\mathrm{AD}$ and $\mathrm{AE}$ genotypes.

None of observed genotypes in this study affected weight at 3, 6, 9, and 12 months. We expect that animals carrying the AD genotype will show a significant difference in weight gain compared with animals carrying the other genotypes. The lack of significant effect of this genotype on weight gain is likely due to inappropriate husbandry as well as the health and nutritional conditions of animals. However, because the polymorphism is in non-coding DNA, drawing conclusions about whether this genetic variation affects myostatin gene activity is difficult. It may affect mRNA splicing or be linked to variation elsewhere in the coding sequence, which subsequently affects the amino acid sequence.

Other relationships between the myostatin gene and growth have been examined. The effect of genetic variation in the myostatin gene on growth and carcass traits has been investigated in 517 male Romney lambs from 17 sire-lines born on a South Island New Zealand 
farm (Hickford et al., 2009). A general linear mixed model revealed that the presence of allele A in lambs is associated with decreases in leg, loin, and total yield of lean meat, whereas the presence of allele B is associated with increases in and proportion of loin yield (Hickford et al., 2009). Several mutations in the myostatin gene may be responsible for various phenotypes in cattle breeds (Grobet et al., 1997; Kambadur et al., 1997; Gill et al., 2009). Li et al. (2002) have identified mutations in exons II and III of the swine myostatin gene. Zheng et al. (2008) have found 2 SNPs in the promoter region of the myostatin gene (T769G, C543T) and one in intron I (A1632G) in 10 goose breeds. Gu et al. (2002), using PCR-SSCP, have scanned the 50 regulatory region, the 30 regulatory region, and part of the coding regions of the chicken myostatin gene and detected 5 SNPs (G167A, T177C, G304A, A322G, and C334T) in the 50 regulatory region and 2 (A6935G and $\mathrm{A} 7263 \mathrm{~T}$ ) in the 30 regulatory region in various chicken lines. They detected no polymorphism in the exon I region.

The work undertaken in the present study was the first attempt to examine the polymorphism of the myostatin locus to understand genetic variability of Makoei sheep in Iran. Very little information is currently available with which to compare various Iranian sheep breeds. Breeding programs in most research centers in Iran have been based solely on phenotypic characters. The current study confirmed the importance of molecular studies in addition to morphological data for the detection of genetic variation among individuals when selecting diverse parents with which to construct a new population. Additional research is needed to characterize the completely ovine myostatin gene variation across an extended region of the gene and in a large variety of sheep breeds from around the world. Of special interest are allele frequencies and the phenotypic effects of myostatin in non-meat breeds, such as merino sheep.

\section{ACKNOWLEDGMENTS}

Research supported by the Institute of Biotechnology, Urmia University, Iran.

\section{REFERENCES}

Bellinge RH, Liberles DA, Iaschi SP, O'brien PA, et al. (2005). Myostatin and its implications on animal breeding: a review. Anim. Genet. 36: 1-6.

Boman IA, Klemetsdal G, Blichfeldt T, Nafstad O, et al. (2009). A frameshift mutation in the coding region of the myostatin gene (MSTN) affects carcass conformation and fatness in Norwegian White Sheep (Ovis aries). Anim. Genet. 40: 418-422.

Clop A, Marcq F, Takeda H, Pirottin D, et al. (2006). A mutation creating a potential illegitimate microRNA target site in the myostatin gene affects muscularity in sheep. Nat. Genet. 38: 813-818.

Crowe ML (2005). SeqDoC: rapid SNP and mutation detection by direct comparison of DNA sequence chromatograms. BMC Bioinformatics 6: 133 .

Georges M, Grobet L, Poncelet D, Royo J, et al. (1998). Positional candidate cloning of the bovine mh locus identifies an allelic series of mutations disrupting the myostatin function and causing double-muscling in cattle. Genet. Appl. Livest. Prod. 26: 195-204.

Gill JL, Bishop SC, McCorquodale C, Williams JL, et al. (2009). Associations between the 11-bp deletion in the myostatin gene and carcass quality in Angus-sired cattle. Anim. Genet. 40: 97-100.

Gong YF, Li XL, Liu ZZ, Jin XM, et al. (2009). SNP detection and haplotype analysis in partial sequence of MSTN gene in sheep. Anim. Genet. 45: 1454-1457.

Grobet L, Martin LJ, Poncelet D, Pirottin D, et al. (1997). A deletion in the bovine myostatin gene causes the doublemuscled phenotype in cattle. Nat. Genet. 17: 71-74.

Gu ZL, Zhang HF, Zhu DH and Li H (2002). Single nucleotide polymorphism analysis of the chicken Myostatin gene in different chicken lines. Yi Chuan Xue Bao 29: 599-606. 
Hadjipavlou G, Matika O, Clop A and Bishop SC (2008). Two single nucleotide polymorphisms in the myostatin (GDF8) gene have significant association with muscle depth of commercial Charollais sheep. Anim. Genet. 39: 346-353.

Herpin A, Lelong C and Favrel P (2004). Transforming growth factor-beta-related proteins: an ancestral and widespread superfamily of cytokines in metazoans. Dev. Comp. Immunol. 28: 461-485.

Herring AJ, Inglis NF, Ojeh CK, Snodgrass DR, et al. (1982). Rapid diagnosis of rotavirus infection by direct detection of viral nucleic acid in silver-stained polyacrylamide gels. J. Clin. Microbiol. 16: 473-477.

Hickford JGH, Forres RH, Zhou H, Fang Q, et al. (2009). Polymorphisms in the ovine myostatin gene (MSTN) and their association with growth and carcass traits in New Zealand Romney sheep. Anim. Genet. 41: 64-72.

Johnson PL, Dodds KG, Bain WE, Greer GJ, et al. (2009). Investigations into the GDF8 g+6723G-A polymorphism in New Zealand Texel sheep. J. Anim. Sci. 87: 1856-1864.

Kambadur R, Sharma M, Smith TP and Bass JJ (1997). Mutations in myostatin (GDF8) in double-muscled Belgian Blue and Piedmontese cattle. Genome Res. 7: 910-916.

Kijas JW, McCulloch R, Edwards JE, Oddy VH, et al. (2007). Evidence for multiple alleles effecting muscling and fatness at the ovine GDF8 locus. BMC Genet. 8: 80.

Kimura M and Crow JF (1964). The number of alleles that can be maintained in a finite population. Genetics 49: 725-738.

Lewontin RC and Hubby JL (1971). A molecular approach to the study of genie heterozygosity in natural populations of Drosophila pseudoobscura. Genetics 54: 595-609.

Li SH, Xiong YZ, Zheng R, Li AY, et al. (2002). Polymorphism of porcine myostatin gene. Yi Chuan Xue Bao 29: 326-331.

Marcq F, Larzul C, Marot V, Bouix J, et al (2002). Preliminary Results of a Whole-Genome Scan Targeting QTL for Carcass Traits in a Texel Romanov Intercross. Proceedings of the 7th World Congress on Applied Livestock Production, Montpellier, 19-23.

McPherron AC and Lee SJ (1997). Double muscling in cattle due to mutations in the myostatin gene. Proc. Natl. Acad. Sci. U. S. A. 94: 12457-12461.

Meyer K (2000). Dfreml User Notes. Version 3.1. New England University, Armidal.

Nishi M, Yasue A, Nishimatu S, Nohno T, et al. (2002). A missense mutant myostatin causes hyperplasia without hypertrophy in the mouse muscle. Biochem. Biophys. Res. Commun. 293: 247-251.

Pipalia DL, Joshi CG, Rank DN, Brahmkshtri BP, et al. (2004). PCR-SSCP typing of MHC in cattle and buffaloes. Indian J. Anim. Sci. 74: 637-639.

Saadat-Noori M and Siah-Mansoor S (1992). Sheep Husbandary and Management. Ashrafi Publication, Tehran.

Smith JA, Lewis AM, Wiener P and Williams JL (2000). Genetic variation in the bovine myostatin gene in UK beef cattle: allele frequencies and haplotype analysis in the South Devon. Anim. Genet. 31: 306-309.

Wiener P, Woolliams JA, Frank-Lawale A, Ryan M, et al. (2009). The effects of a mutation in the myostatin gene on meat and carcass quality. Meat Sci. 83: 127-134.

Yeh FC, Boyle T and Yang R (1997). POPGENE Version 1.31. Microsoft Window-Based Freeware for Population Genetic Analysis. University of Alberta, Edmonton.

Zheng Y, Gong DQ, Wu W, Zhao XT, et al. (2008). Identification and genetic analyses of single nucleotide polymorphisms in goose myostatin gene. Acta Vet. Zootech. Sin. 39: 1320-1328.

Zhou H, Hickford JG and Fang Q (2008). Variation in the coding region of the myostatin (GDF8) gene in sheep. Mol. Cell. Probes 22: 67-68. 